\title{
Konsep Waris Anak Angkat dalam Wasiat Wajibah Perspektif KHI dan Prof. Wahbah Zuhaili
}

\author{
Nur Farikha ${ }^{1}$ dan M. Ali Syaifudin Zuhri ${ }^{2}$ \\ ${ }^{1}$ Fakultas Syariah, IAIN Jember. E-mail: nurfarikha7118@gmail.com \\ ${ }^{1}$ Fakultas Syariah, IAIN Jember. E-mail: alizuhri@gmail.com
}

\begin{tabular}{|c|c|}
\hline Article & Abstract \\
\hline $\begin{array}{l}\text { How to cite: } \\
\text { Nur Farikha \& M. Ali } \\
\text { Syaifudin Zuhri, 'Konsep } \\
\text { Waris Anak Angkat } \\
\text { dalam Wasiat Wajibah } \\
\text { Perspektif KHI dan Prof. } \\
\text { Wahbah Zuhaili' Vol. } 1 \\
\text { No. } 3 \text { Rechtenstudent } \\
\text { Journal Fakultas Syariah } \\
\text { IAIN Jember. } \\
\text { Histori artikel: } \\
\text { Submit } 2 \text { September 2020; } \\
\text { Diterima } 17 \text { November } \\
\text { 2020; Diterbitkan } 7 \\
\text { Desember 2020. } \\
\text { ISSN: } \\
\text { 2723-0406 (media cetak) }\end{array}$ & $\begin{array}{l}\text { When a human couple performs a marriage, then both are not blessed with a child. } \\
\text { One way for the couple is to adopt a child, the law is fine as long as it fulfills the } \\
\text { conditions prescribed by religion. This was done by the Prophet Muhammad. } \\
\text { Adoption of children must meet state requirements, namely through court channels. } \\
\text { Because something related to the rules certainly has a positive impact on the public, } \\
\text { namely maslahah ummah. There are several legal consequences when someone is } \\
\text { adopted as a child, one of which is if one of the adoptive parents or the adopted child } \\
\text { has died there is an appreciation given by one of them. The author conducted this } \\
\text { research to describe the concept of wills for adopted children in the distribution of } \\
\text { inheritance according to KHI and Prof. Wahbah Zuhaili. The author in this study } \\
\text { uses the analytical approach research method, namely an approach that is carried out } \\
\text { by analyzing the thoughts of a character in this case Prof. Zuhaili, and its comparison } \\
\text { with KHI. The conclusion found in this study is the wills of the compulsory will be } \\
\text { something very new in Islam, especially when it comes to adopted children. } \\
\text { Therefore, the concept of inheritance for adopted children is in the form of a } \\
\text { mandatory will, which has been stipulated in the Islamic Law Compilation that a will } \\
\text { when it is not disclosed by the adoptive parents, the adopted child will still receive a } \\
\text { will, at most a third of the assets of the adoptive parents. Meanwhile, Prof. Wahbah } \\
\text { Zuhaili stated that the will is obligatory for relatives and parents (people who are } \\
\text { related by blood) because they are prevented from inheriting. } \\
\text { Keywords: Wasiat obligah, adopted child, Compilation of Islamic Law. } \\
\text { Abstrak }\end{array}$ \\
\hline
\end{tabular}


tua angkat. Sedangkan dalam pandangan Prof. Wahbah Zuhaili menyatakan bahwa wasiat itu wajib untuk kerabat dan orang tua (orang-orang yang memiliki hubungan darah) karena terhalang dari mewarisi.

Kata Kunci: Wasiat wajibah, anak angkat, KHI.

\section{Pendahuluan}

Salah satu tujuan dari perkawinan adalah untuk memiliki keturunan, tetapi tidak semua perkawinan menghasilkan anak atau keturunan. Keinginan seseorang untuk mempunyai keturunan merupakan sebuah naluri manusia, tetapi tidak semua keinginan bisa menjadi nyata karena takdir Tuhan Yang Maha Esa, atau kemungkinan faktor lain yang membuat tidak bisa memiliki keturunan. ${ }^{1}$ Keturunan merupakan aset untuk meneruskan apapun dari orang tuanya, khususnya kelak akan menerima warisan. Oleh karena itu usaha apapun dilakukan untuk mendapatkan anak, salah satunya adalah memungut anak yakni menjadikan anak orang lain sebagai anaknya. Hal ini sudah terjadi baik sebelum maupun sesudah Islam datang di Timur Tengah maupun di Barat.

Ketika seorang muslim ingin memberi kepada seseorang maka agama Islam memberi jalan yaitu dengan cara hibah dan juga wasiat. Namun kedua cara itu ada perbedaan, yaitu jika hibah adalah suatu pemberian yang diberikan untuk menyerahkan hak milik kepada orang lain dalam keadaan sang pemberi masih hidup, sedangkan wasiat adalah suatu pemberian yang mana hak miliknya diberikan kepada orang lain yang mana si pemberi dalam keadaan sudah meninggal.

Hal ini juga berlaku ketika seorang muslim akan memberikan hak miliknya kepada semua orang yang hendak diberinya, khususnya jika seorang muslim mempunyai seorang anak. Namun, bukan anak yang lahir dari rahimnya ataupun bukan berasal dari spermanya, yakni anak angkat maka seorang tersebut boleh-boleh saja memberi warisan terhadap anak angkatnya namun dalam agama Islam pemberian harta dari orang tua angkat bukan disebut dengan warisan namun wasiat wajibah.

Allah SWT mengatur bagaimana cara berwasiat dengan benar, hal itu terdapat dalam Q.S Al Baqarah ayat 180 yang artinya;

"Diwajibkan atas kamu, apabila seseorang di antara kamu kedatangan tanda-tanda maut jika ia meninggalkan harta yang banyak berwasiat untuk ibu bapak dan kerabat secara ma'ruf (ini adalah) kewajban atas orang-orang yang bertakwa."2

Menurut Wahbah Zuhaili dalam kitab tafsir Munir, Q.S Al Baqarah ayat 180 seperti yang telah ditulis di atas adalah dasar hukum yang sangat kuat mengenai wasiat wajibah. Sebagian ulama menafsirkan ayat di atas, bahwa wasiat kepada orang tua dan kerabat asalnya wajib, sampai sekarang kewajiban itu tetap dan diberlakukan. Sehingga pemberian wasiat wajibah kepada walidayn (kedua orang tua) dan aqrabin (kerabat) yang mendapatkan bagian (penerimaan) harta peninggalan, dapat diterapkan dan dilaksanakan.

Sedangkan menurut pendapat lainnya ketentuan wasiat wajibah tidak diterapkan dan dilaksanakan, karena ketentuan wasiat wajibah telah dinasakh baik dalam Al-Quran maupun hadist. ${ }^{3}$ Namun menurut Ibn Hazm mengatakan bahwa wasiat bagi ahli waris yang tidak menerima warisan, maka hukumnya wajib, bahkan beliau mengatakan bahwa wasiat kepada

\footnotetext{
1 Ahmad Junaidi, Wasiat Wajibah Pergumulan antara Hukum Adat dan Hukum Islam di Indonesia (Jember: STAIN Jember Press, 2013), 27-28.

2 Al-Qur'an, 2:180.

${ }^{3}$ Ahmad Junaidi, 119.
} 
orang tua dan kerabat yang tidak mendapat warisan hukumnya fardlu baik karena perbedaan agama, perbudakan atau karena ada ahli waris lain yang menghijabnya. Serta menurutnya sekiranya sebelum pemberi wasiat meninggal maka ahli warisnya wajib mengeluarkan hartanya yang mereka anggap layak.

Sedangkan menurut Ibn Katsir bahwa ayat di atas (Q.S Al-Baqarah: 180) tidak di-naskh tetapi dijelaskan atau ditafsirkan oleh ayat-ayat mawarist. Sedangkan menurut al Qurtubi dalam tafsirnya, ayat tersebut termasuk ayat muhkamat, secara lahiriyah ayat tersebut bersifat umum adapun maknanya bersifat khusus yakni bagi walidayn yang tidak menerima harta warisan, seperti keduanya kafir ,atau hamba sahaya, atau bagi kerabat yang bukan merupakan ahli waris. ${ }^{4}$

Melihat adanya beberapa perbedaan sudut pandang dalam pembagian waris melalui wasiat wajibah dan mengingat kecenderungan penulis terhadap tafsir oleh Prof. Wahbah Zuhaili, penulis akhirnya tertarik untuk mengambil penelitian yang berjudul, "Konsep Waris Anak Angkat dalam Wasiat Wajibah Perspektif KHI dan Prof. Wahbah Zuhaili".

\section{Rumusan Masalah}

Adapun rumusan masalah dalam penelitian ini adalah:

1. Bagaimana konsep wasiat wajibah untuk anak angkat?

2. Bagaimana epistemologi nalar hukum konsep waris anak angkat berupa wasiat wajibah perspektif Kompilasi Hukum Islam dan Prof. Wahbah Zuhaili?

\section{Metode Penelitian}

Jenis Penelitian yang digunakan adalah penelitian kualitatif yang menitikberatkan pada penjelasan teoretis yang ingin dibangun berdasarkan perspektif dan karakteristik daripada penelitian kualitatif yang memfokuskan untuk mendeskripsikan atau menarasikan sesuatu objek yang akan diteliti. Lebih jelasnya lagi penelitian ini merupakan kualitatif pustaka karena sumber penulisan hanya menggunakan undang-undang ataupun buku, baik untuk data primer maupun sekunder.

Pendekatan penelitian yang digunakan pada penelitian ini yaitu analytical approach yaitu pendekatan yang dilakukan dengan cara menganalisis pemikiran seorang tokoh, dalam penelitian ini pemikiran yang harus dikupas lebih mendetail yaitu pemikiran atau asal muasal aturan itu dibuat yaitu aturan hukum Islam yang ada di Indonesia yaitu Kompilasi Hukum Islam dan juga pemikiran dari tokoh Islam kontemporer yaitu Prof. Wahbah Zuhaili. Dalam hal ini bisa dikatakan bahwa penulis menggunakan metode analytical approach yaitu memfokuskan pada menganalisis pengertian hukum, kaidah hukum, sistem hukum dan berbagai konsep yuridis. ${ }^{5}$

\section{Hasil dan Pembahasan}

\section{Konsep Wasiat Wajibah untuk Anak Angkat}

Wasiat wajibah terdiri dari dua suku kata yaitu wasiat dan wajibah, peneliti akan mengupas terlebih dahulu mengenai wasiat. Wasiat adalah iisha' (memberikan pesan, perintah, pengampu, perwalian), dan secara etimologi diartikan sebagai janji kepada orang

${ }^{4}$ Sri Hidayat, "Ketentuan wasiat wajibah di berbagai negara muslim kontemporer", (2012) Jurnal Ahkam Vol XII No 1 Januari, 82.

${ }^{5}$ Johny Ibrahim, Teori \& Metodologi Penelitian Hukum Normatif (Malang: Banyumedia Publishing, 2008 ),310 
lain untuk melaksanakan suatu pekerjaan tertentu semasa hidupnya atau setelah meninggalnya. Wasiat secara istilah menurut ulama figh adalah kepemilikan yang disandarkan kepada keadaan/ masa setelah kematian seseorang dengan cara tabarru' atau hibah, baik sesuatu yang akan dimiliki tersebut berupa benda berwujud atau hanya sebuah nilai guna barang. Wasiat berbeda dengan hibah yang merupakan tabarru' atau pemberian kepemilikan tanpa ganti, karena wasiat dilaksanakan setelah kematian, sedangkan hibah dilaksanakan semasa hidup. ${ }^{6}$

Jika dipandang dari segi hikmah pelaksanaan wasiat, maka hendaklah menyimak firman Allah SWT yang terdapat pada Q.S Al-Maidah ayat 9-10, yang artinya:

"Dan hendaklah takut kepada Allah orang-orang yang seandainya meninggalkan di belakang mereka anak-anak yang lemah yang mereka khawatir terhadap (kesejahteraan) mereka. Oleh sebab itu hendaklah mereka bertaqwa kepada Allah dan hendaklah mereka mengucapkan perkataan yang benar. Sesungguhnya mereka yang memakan harta anak yatim secara zalim, sebenarnya mereka menelan api sepenuh perutnya dan mereka akan masuk kedalam api yang menyala nyala."

Dari ayat di atas dapat disimpulkan bahwa ketika seseorang mati dan meninggalkan harta kekayaan dan uang, maka dia akan mewariskannya. Di antara ahli warisnya adalah anak kecil yang lugu, dia belum pantas membelanjakan hartanya. Kemudian saudaranya yang lain menginginkan untuk menguasai harta tersebut, khususnya orang-orang yang merasa dekat kepadanya dengan menampakkan limpahan kasih sayang dan kelembutan, padahal mereka sebenarnya ingin menguasai harta tersebut secara dzalim. Oleh karena itu hikmah disyariatkan dari wasiat yaitu seorang anak yang masih lugu telah mempunyai pelaksanaan wasiat yang menyayanginya dan dapat dipercaya. ${ }^{7}$

Hukum asalnya wasiat adalah sunnah karena di dalamnya terdapat unsur tabarru'. Namun, kembali pada niat dan kondisi atau objek yang akan dikenai hukum wasiat, maka hukumnya menjadi bermacam-macam. Penulis akan membahas tentang wasiat yang berhukum wajib. Wasiat wajib adalah memberikan kepemilikan setelah kematiannya kepada orang lain yang bersifat mengharuskan si pemberi wasiat untuk melaksanakan wasiat. Sedangkan dari pengertian lain, wasiat wajibah adalah pemberian harta kepada pihak lain karena pihak lain tersebut terhalang untuk diberi harta warisan yang mana pemberian harta ini bersifat wajib baik orang yang memberi itu suka rela ataupun tidak karena hal ini ditindaklanjuti oleh penguasa atau hakim. Wasiat wajibah merupakan bukti bahwa pelaksanaan wasiat itu tidak tergantung dari harapan pemberi wasiat. Hal tersebut berdasarkan ketentuan wasiat wajibah yang berdasarkan interpretasi dari ayat 180 surah $\mathrm{Al}$ Baqarah, di ayat tersebut dikatakan bahwa ada perintah bagi orang-orang yang takut kepada Allah untuk berwasiat bagi orang tua dan kerabat sebelum mereka meninggal. ${ }^{8}$

Wasiat wajibah diatur dalam pasal $209 \mathrm{KHI}$, dari sudut teori hukum kedudukan wasiat wajibah yakni "Setiap orang beragama tunduk kepada hukum agama yang dianutnya, suatu pesan yang bersumber kepada teori receptie a contrario yang menyatakan bahwa hukum adat baru berlaku jika ia tidak bertentangan dengan hukum Islam." Sejiwa dengan teori tersebut, L.W.C van den Berg berpendapat bahwa hukum yang berlaku di Indonesia adalah undang-

\footnotetext{
${ }^{6}$ Wahbah Zuhaili, Fiqih Islam Wa Adillatuhu, terj. Abdul Hayyie al-Kattani dan Budi Permadi, (Jakarta: Gema Insani, 2011, jilid 10), 155

${ }^{7}$ Ali Ahmad Al Jurjawi, Terjemah: Hikmah Dibalik Hukum Islam Bidang Muamalah, (Beirut: Darul Fikr, 2003), $256-257$

8 Sri Hidayat, "Ketentuan wasiat waibah di berbagai negara muslim kontemporer" (2012) ,Jurnal ahkam Vol XII No 1 Januari, 81
} 
undang agama yang mereka yakini sebagai hukum Islam. Teori ini dikenal dengan teori receptie in complex yang sejak tahun 1855 telah didukung oleh peraturan Hindia Belanda melalui pasal 75,78, dan 109 RR 1854.

Wasiat wajibah dalam KHI Buku II Pasal 171 huruf f disebutkan bahwa wasiat adalah pemberian suatu benda dari pewaris kepada orang lain atau lembaga yang akan berlaku setelah pewaris meninggal dunia. Wasiat wajibah harus memenuhi dua syarat, yakni;

1. Yang wajib menerima wasiat bukan waris. Kalau dia berhak menerima pusaka walaupun sedikit tidaklah wajib dibuat wasiat untuknya.

2. Orang yang meninggal, baik kakek maupun nenek belum memberikan kepada anak yang wajib dibuat wasiat, jumlah yang diwasiatkan dengan jalan yang lain, seperti hibah. ${ }^{9}$

Menurut Alyasa Abu Bakar, metode ijtihad dalam menetapkan wasiat wajibah bagi anak dan orang tua angkat adalah karena aspek kemaslahatan dan penghargaan hubungan baik antara anak dengan orang tua angkat.

\section{Epistemologi Nalar Hukum Konsep Waris Anak Angkat Berupa Wasiat Wajibah} Perspektif Kompilasi Hukum Islam dan Prof. Wahbah Zuhaili

Dalam Bahasa belanda mengangkat anak diartikan sebagai adaptive zoon. Sedangkan dalam Bahasa Inggris adalah adaption of child. Dalam kamus umum Bahasa Indonesia, anak angkat secara terminologi adalah anak orang lain yang diambil dan disahkan sebagai anaknya sendiri, dalam hal ini juga disebut sebagai salah satu cara untuk mengadakan hubungan antara orang tua dan anak, sesuai yang diatur dalam perundang-undangan. ${ }^{10}$

Menurut Surojo Wignodipurno, anak angkat adalah suatu perbuatan pengambilan anak orang lain ke dalam keluarganya sendiri sehingga antara orang tua yang mengangkat anak dan anak yang dipungut itu timbul suatu hubungan kekeluargaan yang sama seperti hal nya orang tua dengan anak kandungnya sendiri. ${ }^{11}$ Dalam Pasal 39 ayat (2) UU No. 23 Tahun 2002 tentang Perlindungan Anak juga disebutkan, pengangkatan anak sebagaimana dimaksud ayat (1), tidak memutuskan dalam hubungan darah antara anak yang diangkat dengan orang tua kandungnya. Menurut hukum formal di dalam Islam, pengangkatan anak mengacu pada Kompilasi Hukum Islam (KHI). Mengenai pembagian waris kepada anak angkat pun telah dijelaskan di dalam Kompilasi Hukum Islam, berikut penjabaran serta perbandingannya dengan pendapat yang dikemukakan oleh Prof. Wahbah Zuhaili.

\section{a. Wasiat Wajibah untuk Anak Angkat dalam Kompilasi Hukum Islam}

Sesuai definisi dalam KHI Pasal 171 poin $h$, anak angkat adalah anak yang dalam pemeliharaan untuk hidupnya sehari-hari, biaya pendidikan dan sebagainya beralih tanggung jawabnya dari orang tua asal kepada orang tua angkatnya berdasarkan putusan pengadilan. Status atau kedudukan anak angkat menurut KHI adalah tetap sebagai anak yang sah berdasarkan putusan pengadilan dengan tidak memutuskan hubungan nasab darah dengan orang tua kandungnya, dikarenakan prinsip pengangkatan anak menurut Kompilasi hukum Islam adalah merupakan manifestasi keimanan yang membawa misi kemanusiaan yang terwujud dalam bentuk memelihara orang lain sebagai anak, serta memelihara pertumbuhan dan perkembangannya dengan mencukupi segala kebutuhannya. Mahmud Saltut

\footnotetext{
9 Tengku Muhammad Hasbi, Figh Mawaris (Semarang: PT Pustaka Rizki Putra, 2010), 265

${ }^{10}$ Budiarto, Pengangkatan Anak Ditinjau dari Segi Hukum (Jakarta:Akapress, 1991), 56

11 Surojo Wignodipuro,Asas-Asas Hukum adat, (Jakarta:Kinta,1972),14
} 
menegaskan bahwa perlakuan terhadap anak angkat haruslah dengan penuh kecintaan dan rasa sayang tanpa menjadikannya sebagai anak angkat. ${ }^{12}$

Kasus pengangkatan anak pernah terjadi dalam sejarah Islam yakni pada zaman nabi Muhammad SAW. Beliau sendiri yang mengangkat seorang anak bernama Zaid bin Haristah. Pengangkatan anak dalam Islam, nasab atau keturunan karena pertalian darah tidak boleh dihilangkan. Nasab anak tetaplah mengacu kepada ayah kandungnya, jadi Zaid tidak dipanggil dengan Zaid bin Muhammad, melainkan Zaid bin Haristah.

Pengangkatan anak sejak zaman dahulu sudah merata di seluruh wilayah Indonesia. Anak angkat tersebut diperlakukan sepenuhnya seperti anak kandung. Namun dalam konteks hukum waris, anak tersebut masih berpotensi atas harta kekayaan orang tua kandungnya, begitu juga atas harta kekayaan orang tua angkatnya.

Sebelum tahun 2006 beberapa Pengadilan Agama melayani permohonan anak angkat. Dalam hukum adat anak angkat sudah sama halnya diperlakukan seperti anak kandung, sedangkan dalam hukum Islam tidak boleh menyamakan antara anak angkat dengan anak kandung, tidak boleh memutuskan hubungan keluarga darah dengan orang tua dan saudara kandungnya, tidak berhak menjadi ahli waris dan lain sebagainya, sebaliknya jika orang tua angkat meninggal, dan tidak meninggalkan anak kandung, maka anak angkat berhak mewarisi seluruh harta warisan. Bila anak kandung ada, maka bagiannya sama seperti anak kandungnya, hal seperti ini mendapat respons dan toleransi ulama Indonesia, dengan memberi bagian warisan melalui wasiat wajibah maksimal 1/3 harta warisan.

Pemberlakuan wasiat wajibah mempengaruhi peralihan nilai hak warisan dari ahli waris yang lain. Istilah wasiat wajibah dalam hukum Islam klasik tidak pernah dikenal. Anak angkat selama ini tidak memiliki tempat dalam hukum Islam untuk memperoleh bagian warisan. Wasiat merupakan produk ijtihad ulama di Indonesia yang secara substansi menurut pendapat ulama di timur tengah yang berlakukan wasiat wajibah. Di Indonesia ditujukan untuk anak angkat sedangkan di dunia Islam ditujukan untuk cucu pancar perempuan.

Berikut adalah ketentuan-ketentuan dalam Pasal 209 KHI menurut Habiburrahman, sesuai dengan teori maslahah al-ummah terhadap anak angkat yang dapat memperoleh bagian sebagai wasiat wajibah dari harta warisan dengan rekonstruksi pemikiran sebagai berikut: ${ }^{13}$

1. Anak angkat diperbolehkan hanya sebatas pemeliharaan, pengayoman, dan pendidikan. Dilarang memberi status layaknya anak kandung.

2. Anak angkat bisa mendapatkan harta dari orang tua angkat berdasarkan ketentuan wasiat yang besarnya tidak melebihi sepertiga harta orang tua angkatnya yang telah meninggal dunia, bila orang tua angkatnya tidak meninggalkan wasiat maka berhak mendapatkan wasiat wajibah.

3. Pemberi wasiat wajibah tidak boleh merugikan hak-hak dari ahli waris.

4. Bila ada sengketa tentang status anak angkat harus dibuktikan dengan adanya putusan pengadilan.

5. Bila ada sengketa tentang wasiat atau wasiat wajibah bagi anak angkat, maka harus ada putusan pengadilan yang menyatakan anak angkat tersebut berhak atas wasiat wajibah, tetapi petitum khusus untuk dinyatakan berhak mendapat wasiat wajibah tidak ada, karna ketentuan dalam KHI bersifat imperatif, harusnya merujuk Al-Quran yang mensyaratkan pewaris meninggalkan harta banyak. Demikian ulama tafsir telah

12 Ahmad Junaidi, 30.

${ }^{13}$ Habiburrahman, Rekonstruksi Hukum Kewarisan Islam di Indonesia , (Jakarta: Kementrian Agama RI, 2011$), 188$ 
menafsirkan kata khairan dalam ayat 180 surat al-Baqarah yang ditulis diatas sebagai dalil adanya wasiat wajibah.

\section{b. Wasiat Wajibah untuk Anak Angkat dalam Pandangan Prof. Wahbah Zuhaili}

Epistimologi nalar adalah pertimbangan tentang baik dan buruk atau aktivitas yang memungkinkan seseorang berpikir logis dengan jangkauan pikiran dan kekuatan pikir. Jadi sederhananya penalaran hukum yaitu berpikir, menggunakan, mengembangkan atau mengendalikan suatu masalah dibidang hukum dengan nalar. Dalam hal ini terdapat beberapa langkah untuk mencapai suatu produk hukum, di antaranya adalah sesuatu hal yang melatarbelakangi yang belum pernah terjadi sebelumnya, selanjutnya dianalisis sesuatu hukum yang mana yang cocok dengan permasalahan tersebut, dan dicari sebab dan dampak hukum yang akan terjadi lalu solusi hukum apa yang tepat untuk permasalahan tersebut.

Prof. Wahbah Zuhaili dalam kitabnya Fiqhul Islam Wa Adillatuhu menjelaskan wasiat kepada kerabat hukumnya disunahkan menurut jumhur ulama yang diantaranya adalah Imam empat madzhab. Wasiat itu tidak wajib bagi seseorang kecuali sebab hak dari Allah atau bagi para hamba Allah. Sebagian para ahli fiqih seperti Ibnu Hazm Ad Dzahiri dan atThabari dan Abu Bakar bin Abdil Aziz dari ulama madzhab Hambali berpendapat bahwa wasiat adalah kewajiban agama dan pembayaran kewajiban bagi kedua orang tua dan para kerabat yang tidak mendapatkan bagian warisan karena terhalang dari mewarisi. Adapun Undang-Undang Mesir Pasal (76-79) dan Undang-Undang Syria Pasal (257) menggunakan pendapat yang kedua yaitu mewajibkan wasiat untuk orang-orang yang terhalang mewarisi. Wasiat ini tidak memenuhi ketentuan-ketentuan wasiat yang dilakukan secara sukarela karena tidak ada ijab dari orang yang memberi wasiat dan tidak ada qabul dari penerima wasiat, maka wasiat wajibah ini menyerupai waris, sehingga diperlakukan seperti warisan yaitu bagian laki-laki mendapat dua kali lipat dari bagian perempuan dan ahli waris yang asal menutupi cabangnya dan setiap cabang mengambil bagian dari asalnya. ${ }^{14}$

Jadi aturan yang berada pada UU Hukum Waris yang ada di Mesir sejalan dengan pendapat beliau, sedangkan pada aturan yang terdapat pada Kompilasi Hukum Islam objek penerima wasiat sangat berbeda. Karena illat yang terdapat pada pernyataan kedua dari beliau yaitu memiliki hubungan darah (genetik), sedangkan anak angkat tidak memiliki hubungan darah dengan orang tua angkat.

\section{Kesimpulan}

Istilah wasiat wajibah merupakan hal baru dalam dunia Islam, pertama kali yang mempergunakan istilah tersebut adalah negara timur tengah, yaitu Mesir. Ketentuan itu terdapat pada UU Hukum Waris 1946 yakni untuk membantu cucu yang tidak memperoleh hak warisnya. Selain negara Mesir yang menggunakan istilah wasiat wajibah, diikuti oleh negara timur tengah lainnya yaitu negara-negara mayoritas Muslim seperti Tunisia, Yordania, Syria, dan juga termasuk Indonesia mengambil konsep tersebut. Namun terdapat objek yang berbeda tentang hukum mengenai konsep wasiat wajibah ini, yaitu jika di negara bagian timur tengah khususnya Mesir objek penerima wasiat yaitu cucu yang terhalang mendapat warisan karena terhalang oleh ahli waris yang lebih dekat seperti saudaranya orang tuanya, sedangkan orang tuanya sendiri telah meninggal dunia. Sedangkan di Indonesia objek penerima wasiat wajibah yaitu anak angkat dan orang tua angkat, yang mana hal tersebut

\footnotetext{
${ }_{14}$ Wahbah Zuhaili, Fiqih Islam Wa Adillatuhu, terj. Abdul Hayyie al-Kattani dan Budi Permadi,(Jakarta: Gema
} Insani, 2011, jilid 10),245 
tidak sejalan dengan pernyataan Prof. Wahbah Zuhaili dalam kitab Fiqhul Islam wa Adillatuhu, yaitu wasiat merupakan kewajiban agama dan pembayaran kewajiban bagi kedua orang tua dan para kerabat yang tidak mendapatkan harta pusaka karena terhalang dari mewarisi. Jadi pengertian wasiat wajibah tersebut hanyalah orang tua, saudara atau kerabat karena memiliki hubungan darah. Sedangkan dalam Kompilasi Hukum Islam objek penerima wasiat wajibah tidak memiliki hubungan darah.

\section{Daftar Pustaka}

\section{Buku}

Ahmad, Junaidi. 2013. Wasiat Wajibah Pergumulan antara Hukum Adat dan Hukum Islam di Indonesia. Jember: STAIN Jember Press.

Ali, Ahmad Al Jurjawi. 2003. Hikmah dibalik hukum Islam bidang muamalah Terj. Erta Mahyudin Firdaus dan Mahfud Lukman Hakim, Jakarta: Mustaqim.

Anshori, Abdul Ghofur. 2011. Filsafat Hukum Hibah dan Wasiat di Indonesia. Yogyakarta: Gajah Mada University Press.

Budiarto. 1991. Pengangkatan Anak Ditinjau dari Segi Hukum. Jakarta: Akapress.

Habiburrahman. 2011. Rekonstruksi Hukum Kewarisan Islam di Indonesia. Jakarta: Kementrian Agama RI.

Johny, Ibrahim. 2008. Teori \& Metodologi Penelitian Hukum Normatif. Malang: Banyumedia Publishing.

Muhammad, Hasbi Tengku.2010.Figh Mawaris. Semarang: PT Pustaka Rizki.

Surojo, Wignodipuro.1972.Asas-Asas Hukum adat. Jakarta: Kinta.

\section{Kitab}

Zuhaili, Wahbah. 2011. Fiqih Islam Wa AdillatuhuTerj. oleh Abdul Hayyie al-Kattani dan Budi Permadi. Jakarta: Gema Insani.

\section{Jurnal}

Hidayat, Sri. "Ketentuan wasiat waibah di berbagai negara muslim kontemporer" (2012) Jurnal Ahkam Vol XII No 1. 